\title{
Urban Geography in Postwar Japan
}

\author{
Kazutoshi AвE \\ Department of Geography, Aichi Univ. of Education, Kariya 448, Japan
}

\begin{abstract}
The postwar development of Japanese urban geography is divided into four periods. The amount of research in urban geography has increased, expanding study targets and analytical methods. With an increase in studies of urbanization in the 1950s, heated debate ensued and stimulated urban geographers, leading to the subsequent development of urban geography. There are two approaches, to regard a city as a specific point or as an area. The former is represented by studies on the central place and the urban system, while the latter is represented by studies on the internal structure of a city. These two have been dealt with almost equally by Japanese urban geographers. The trends of urban geography comprise the following points: an emphasis on the functional aspects; the introduction of more quantitative approaches; and an increase in the number of studies of foreign cities. Two points are indispensable for the further development of Japanese urban geography: controversy and theorization. The implications of the former are evident, judging from the role that debate played in the initial urbanization controversy. Clearly, progress cannot be made without dispute and debate. Theorization is equally important. Quantitative geography was originally oriented toward theory, although theorization can be accomplished without the use of a quantitative approach. Whether quantitative or nonquantitative approaches are taken depends on the attitude of researchers, but both provide Japanese urban geography, which has traditionally depended on imported foreign accomplishments for its development, with an opportunity to transmit information internationally.
\end{abstract}

Key words: urban geography, central place, urban system, internal structure of a city, quantitative approach

\section{Introduction}

This paper summarizes studies of urban geography in the postwar period in Japan. The description is arranged chronologically and the characteristic features of each decade are examined, since it is very difficult to arrange the ever-increasing number of studies of urban geography into a simple and precise order.

A city comprises population, and commercial, transportation, and industrial facilities; it also has political, economic and cultural functions; and urban studies naturally cannot disregard the lapse of time called history. Although urban study includes all these aspects, neither the industrial and historical aspects nor the urban studies of population and transportation are discussed in this paper.

This paper analyzes the mainstream of study trends in urban geography, making use of: 1) Geographical Bibliography (Chirigaku Bunken Mokuroku) compiled by the Human Geographi- cal Society of Japan; 2) Results and Problems of Economic Geography (Keizai Chirigaku no Seika to Kadai) compiled by the Japan Association of Economic Geographers; and 3) The "Review" column of Human Geography (Jimbun-Chiri), an academic journal published by the Human Geographical Society of Japan.

Some researchers have tried to chart the development of urban geography in Japan (Yamaga 1973; Tanabe 1975, 1985; Kiuchi 1979; Takahashi, N. 1980a; Takahashi and Kanno 1988; Yamaguchi 1988; Yamada 1988). Reading their articles together with this paper will facilitate further understanding of the development of urban geography in Japan.

\section{Position of Urban Geography from the Viewpoint of Bibliography}

The three sources published by geographers' associations previously mentioned provide a regular opportunity to review studies of human geography in Japan. The first important issue 
to be raised is that none of these three publications had an urban geography category in the beginning of the series. This shows that urban geographers had not produced enough studies to be allocated an independent chapter.

Urban geography appeared as an independent item in the fifth volume of Geographical Bibliography (published in 1973, covering the 1967-71 period), and in the second volume of Results and Problems of Economic Geography (published in 1977, covering the 1966-75 period). In earlier volumes, urban geography was included either within settlement geography (Geographical Bibliography) or within rural/ urban geography (Results and Problems of Economic Geography). Both rural geography and urban geography were considered to form part of settlement studies dealing with human settlement areas. In fact, until the early 1960s, the study of rural areas was more popular than urban study. Human Geography gave space to urban geography as a subcategory of settlement geography as early as 1955, and urban geography was allocated an independent chapter in 1959, much earlier than the other two sources, because its annual publication made it easy to judge the trends and research results of the time. It is interesting that even these three sources, which reflect the general trends of research, included the research results of urban geography only as a part of settlement or rural geography, and treated them as a mere addition in the beginning. This shows the rather low profile of urban geography in postwar Japan up to the early 1960s, to say nothing of the prewar period.

Several series of books have been published to introduce the results of geographical studies. A series published in the 1950s included a volume containing urban geography (Kiuchi 1955), but it was entitled Population/Settlement Geography, although the editor was one of the pioneer urban geographers in Japan. Another important geographical series published in the 1960s also included a volume entitled Urban/ Rural Geography (Kiuchi 1967), which was shared equally by urban and rural geography. A series published in the 1980s finally allotted one volume to Urban Geography (Tanabe and Watanabe 1985).

\section{Development of Urban Geography}

\section{The 1950s}

Urban geography and its development are closely related to the urbanization of Japanese society. There is no doubt that urban geography made its greatest advances after World War II. To be sure, such pioneer researchers as Odauchi (1918) and Kunimatsu (1934) published some urban studies in the prewar period. Japan was in confusion for a few years after the end of the war, and it was only in the 1950s that studies in urban geography started to make real progress, as was true for many other fields of research. Kiuchi (1951) paved the way for the postwar development of urban geography. This book treated the distribution of cities and spacial structure within a large city, and also summarized past studies in urban geography. Aside from this book, quite a few studies were published at about the same time (Tanabe 1949; Kobayashi 1950; Yamaga 1950; Higuchi 1956). Many of those studies dealt with the classification of cities, metropolitan and urban regions, satellite cities, rural-urban relations, the internal structure of a city, changes in the suburbs on metropolitan fringes and cities as central places.

Research trends in this period can be summarized as follows: 1) more emphasis was placed on the functional aspects than on the morphological aspects; 2) there was an increase in the number of studies on changes in metropolises and their impact on their suburban areas; 3) Christaller's central place theory was applied more often to studies in Japan; and 4) many studies had historical viewpoints. This last point implies that even though geographers had a profound knowledge of history in those days, they were not the only researchers to undertake urban studies. This point is illustrated by Fujioka $(1955,1968)$ who had always included his historical viewpoint in his urban studies.

It should be kept in mind that the development of urban geography was largely due to the stability and prosperity enjoyed by Japanese society in the postwar period, which are 
attributed to industrialization and urbanization, with a remarkable growth of cities and accompanying regional changes in a very short period. Under these circumstances, the Association of Japanese Geographers held symposia entitled "The Suburbs of a City" (1955) and "Urbanization" (1959).

However, few studies dealt with foreign cities or city planning. In the case of city planning, it was more interesting for geographers to study the actual aspects of Japanese cities than to focus on application aspects such as city planning. This passive approach of urban geographers in general to city planning persists even today. Modern urban geographers have had a strong tendency to think more of basic analysis than applications relating to various city problems since the initial period.

Together with an increase in studies on urbanization, heated debate ensued centering on the definition of urbanization, represented by Takano (1959) and Ishimizu (1962). Takano defined urbanization in a narrow sense, claiming that urbanization meant a change of an area from rural to urban conditions, while Ishimizu insisted that the definition of urbanization should be widened and that urbanization included in fact a situation where an already urban region or city became more urbanized. The Urbanization Study Group (1958-1964) established within the Association of Japanese Geographers played a major role in holding a symposium on urbanization in 1959 , followed by a series of papers published in book form (Kiuchi et al. 1964).

The major discussion included not only that about definition, but also about factors contributing to urbanization, and focused on evaluation of the impacts of industrialization on urbanization. This dispute never reached a conclusion, but it stimulated many young urban geographers, leading to the subsequent development of urban geography.

\section{The 1960s}

The research of this period focused on the metropolitan areas, non-metropolitan cities, and central places. Research on the metropolitan areas, especially on the Tokyo and Osaka regions, was extensive.
Metropolitan research in this decade was mainly divided into that on areas influenced by the metropolis, internal structure, and urban problems such as overcongestion and housing problems. Expansion of metropolitan influence was analyzed in terms of definition of the metropolitan area, and suburban or satellite cities, culminating in Yamaga (1967) who studied at length the transformation of the suburban areas and cities around Tokyo. However, many studies that delineated a metropolitan area, with the exception of Takano (1962), utilized only official data on commuters, or traffic flow, because the volume of a relevant sample was too large for an individual researcher to handle.

The internal structure of the metropolis was also studied with the theories of Burgess, Hoyt, and Harris and Ullman in mind. Otherwise, many studies analyzed Japanese cities with reference to the CBD studies by Murphy or Vance, Jr. Among others, Hattori (1969) analyzed the internal structure of Tokyo, and Osaka City Office (1970) made a detailed analysis of the city centers of Osaka, Nagoya, Yokohama, Kyoto, Kobe and Kitakyushu.

A further important point about the analytical view of the metropolis is the appearance of research on the central management function, which, as the highest-level urban function, attracted the attention of the Economic Planning Agency in the early 1960s. It came to be identified as the key to clarifying the mechanisms involved in the growth of a metropolis or a major city. In the beginning, urban studies from the standpoint of this function were mainly undertaken by public organizations, led by some urban geographers. This research view point came to play an important role in the studies of regional central cities as well as in those of metropolises such as Tokyo, Osaka and Nagoya.

Much research on non-metropolitan cities was reported, because these grew in their own way to impose a stronger impact on their surrounding areas in this period. Some cities expanded their influence beyond their prefectural boundaries, as in the case of the regional central cities. As miniature versions of the metropolis, such cities are easier to handle due to their relative simplicity, thus enabling geographers 
to attain their research objectives. A regional central city (koiki chushin toshi) literally means a city whose influence reaches an extended area. Playing an important role among Japanese cities, the regional central city was taken up in many later studies. Kitagawa (1962) was the first researcher to study it, and early studies were also conducted by Yoshida $(1970,1972)$.

Central place study started in Japan in the 1950s (Watanabe 1954, 1955), and made great strides in the 1960s with Morikawa (1959, 1961, 1968, 1969) and Nishimura (1965), illustrating that the main focus of urban study had shifted from morphological aspects to functional aspects.

Rank-size rule, economic base theory and location quotient were also applied (Narita 1967), reflecting a stronger tendency to clarify the issues by processing data obtained, as in the case of computation of centrality, rather than using the traditional method. This research trend stems from the development and introduction of quantitative approaches which became very popular not only with urban geographers but also with other geographers in the latter half of the 1960 s.

Through urban growth and expansion, studies on suburban development and the problems of urban cores increased in number. In the 1960s when Japan was in its high economic growth period; urbanization proceeded remarkably quickly (Takahashi, N. 1968), and urbanization increased the impact on the peripheral areas and urban renewal of urban cores. While encouraging the study of suburban/satellite cities, studies on the increased impact of urbanization on the fringe areas attracted urban geographers' attention to various problems accompanying land development for housing, "new town" construction (Ogasawara 1967; Yamaga 1968), and problems of environmental disruption. In the study of urban renewal of the metropolis, CBD studies and those on central commercial areas made a great contribution (Higuchi 1963; Kuwajima 1964; Sugimura 1967).

The studies of this period were also characterized by increasing studies on foreign cities. Much research focused on North American or Asian cities, largely because of the closer rela- tions with these countries and easier access to them from Japan.

Among others, AJG (1970) must be mentioned as an epoch-making publication. This book consists of eight sections: recent trends in Japanese urban geography; historical aspects; urbanization and urban population; urban land use and landscape; urban structure; functional activities; urban transportation; and urban problems and planning. It was inconceivable in the 1950s that the research capacity of Japanese urban geography would develop so that such a book could be published. Publication of this book is a proof of the tremendous progress that Japanese urban geography made in the 1960 s.

\section{The 1970s}

The 1970s were a period of great excitement for Japan. High economic growth, which had lasted for over ten years, came to a standstill because of the two oil crises. The national regional policy coped with this trend, controlling the urban concentration of the population and industries and promoting regional development. As a result, population inflow into the three metropolitan regions of Tokyo, Osaka and Nagoya slackened, while the growth of the major regional cities did not slow down. The employment rate in tertiary industry greatly increased, contributing to a greater increase in urban geographical studies in the 1970s than before.

With the increased number of articles published on urban geography in the 1970 s, symposia at the annual meetings of geographic societies often featured themes related to urban geography. Studies on the metropolis were continually focused on the metropolis itself and its impact on the surrounding areas. Much research was done on population concentration in the metropolis (Otomo 1979) and on urban functions. This resulted in the publication of books on the internal structure of the city. Kuwajima (1971) studied the internal structure of Sendai, while Tanabe $(1971,1973)$ compared the internal structure of Japanese cities with those of selected foreign cities. Higuchi (1979) made a comparative analysis between the internal structure of Japanese cities, including 
Osaka and Nagoya, and those of East Asian metropolises, including Seoul and Taipei. All these suggested the influence of studies in the United States. Numerous results from commercial geography were also published as a part of research on the internal structure of a city. Hattori and Sugimura (1974), Sugimura (1975), and Hattori et al. (1980) were studies either with central place study in mind or with detailed analysis of locational trends by type of industry. Population geography offered a large accumulation of studies, analyzing the city and region with population as an indicator (Nishihara 1975; Ishimizu and Ishihara 1980).

Studies focusing on the vertical townscape are as important as those on the internal structure of the city. Todokoro's pioneering papers $(1973,1975)$ led to the publication of his work on vertical growth of the city (Todokoro 1986). Japanese cities had a low- to medium-level structure for a long time. However, the concentration of various functions in the city center called for urban renewal. Tanabe et al. (1977) took up this theme and made a case study of several cities based on their research results from the study of the internal structure of the city.

Commerce, whether retail or wholesale, is an important research subject in urban geography. The retail industry can also be analyzed by shopping district, central place and urban region studies. Kohsaka $(1972,1976)$ studied city trade areas from the viewpoint of consumer shopping behavior, and paved the way for increased study on this subject. Because the wholesale industry influences a wider area than the retail industry, the former is taken up to observe the extent of a regional central city's influence on intercity linkages in an extensive area. Hasegawa (1974a, 1974b) took Sendai as the regional central city and analyzed the wholesale region and function in Tohoku.

This decade also saw remarkable expansion of urban regions around the metropolises, and urban geography always tried to delineate urban regions. Sawada, who had been working on that theme for a long time, finally published his studies (Sawada 1978). Tomita $(1975,1977)$ made a detailed analysis of the three metropolitan areas from the viewpoint of population and industry, and proposed a structural transformation model of the metropolitan area, which was always an attractive research target for urban geographers. However, the size of the subject makes it almost impossible for an individual researcher to tackle it without selecting a specific theme, and some sort of collaboration was often worked out. Some comprehensive research results concerning metropolitan areas include a study on the Nagoya metropolitan area (Ito, G. 1972).

What should be noted about metropolitan studies in this decade is the further progress of urban analysis made from the viewpoint of a central management function. This function is a useful indicator for major cities for comparison at a national level, leading to a rapid increase in the number of research reports focusing on the central economic management function. Because of its concentration on the urban core, it also came to play an important role as a part of studies on the city's internal structure. In addition, since it is considered to be an important urban function, this theme was often taken up in studies on the regional central city.

Study results on the regional central city followed in quick succession, and became characteristic of this period. Kiuchi and Tanabe (1971) discussed the current conditions and research themes of the regional central city based on the 1969 symposium. Kitagawa (1976) published his research on the regional central city which he had been compiling since 1962. Much research was undertaken on nonmetropolitan cities, taking the same approach as metropolitan studies. Many of the abovementioned studies, whether metropolitan or non-metropolitan, were related to urbanization (Takahashi, N. 1979, 1980b).

Urbanization consists of many aspects that change with the lapse of time, making it difficult for one researcher to analyze the entire phenomenon. The situation becomes much more complex if urbanization of a metropolitan region is studied. This accounts for the occasional publication of comprehensive joint studies such as Aoki et al. (1979).

Central place studies in the 1970s (Hayashi 1973; Morikawa 1974; Tsutsumi 1975; Hayashi and Ito 1976) took the basic stance that the 
central place theory could be also applied in Japan. While much of Japanese central place research focused on inductively pointing out the hierarchy in central places, Nishimura $(1965,1977)$ focused on the relationship between the centrality index and distance, and the construction of the equilibrium circle, deductively. Central place studies became known as the academic field with the richest reserve of researchers in Japanese urban geography.

In the 1970s, urban geography was challenged by a great new wave, that is, the introduction of quantitative approaches (Okuno and Nishioka 1976; Takahashi, J. et al. 1976), whose introduction had already been heralded in the 1960s. Although the entire field of geography was subjected to this challenge, urban geography was the most affected. With introductory work (Ishimizu and Okuno 1973; Suzuki 1975; Takahashi, J. 1975; Ishimizu 1976; Okuno 1977) published, quantitative approaches became more accessible, being influenced by the boom in quantification in the United States and the United Kingdom.

Factor analysis, cluster analysis, trendsurface analysis, graph theory and gravity model were increasingly used. The computation in this period clearly differed from that in the past in view of the fact that a large quantity of data was now processed in a complex manner. Construction of models and a strong tendency toward theorization were also characteristics of research that adopted quantitative approaches, which certainly enriched urban geography. Themes such as classification of cities (Yamaguchi 1972, 1973; Morikawa 1976), which had been disregarded for a long time, came to be analyzed quantitatively in preference to the conventional method. However, it cannot be said that sufficient discussion occurred in geographers' associations in regard to the validity and limitations of quantitative approaches, or in regard to the difference from nonquantitative research results and contributions to the theoretical basis of urban geography.

\section{From 1981 to the present}

As a consequence of the increasing number of articles throughout the 1980 s and to the present day, the widening research targets, and the resulting increase in competition with border sciences, some geographers have pointed out the danger of confusion or disorientation of urban geography. Generally speaking, however, urban geography continues to develop up to the present day, reflecting the fact that Japan has persistently taken the course of urbanization, and that the role of tertiary industry has increased so much that the economy is becoming more service- and information-oriented.

Much research was directed at the metropolis (Fujii 1990) again in the 1980s, particularly in the Tokyo metropolitan area which unprecedentedly grew and expanded. At the same time, many studies were conducted on nonmetropolitan cities, with remarkable results from the standpoint of central place theory.

What should be noted about urban geographical studies in this period is the increase in the number of studies on urban systems. Furthermore, studies on counterurbanization, reurbanization, information and human existence, and foreign cities also increased remarkably. Additional introduction and precision of quantitative approaches also proceeded.

A concentration in Tokyo of a large population, functions, funds and information was so predominant that the phrase "single-point concentration" was coined. Recognizing this phenomenon as an important problem, the Japanese government proposed a national plan that would create some major centers with the aim of improving the regional structure based on the single-point concentration in Tokyo. On the other hand, the development of Tokyo has been basically guided by spontaneous forces of a laissez-faire nature, and there is a strong call for the growth of Tokyo as a world city.

With this situation in mind, a special issue of Geographical Review of Japan (1990) featuring Tokyo studies was published to inform the world of the results of geographical studies on Tokyo, and a symposium on the metropolitan areas was held at the 1992 annual meeting of the Association of Japanese Geographers, where there was considerable interest in Tokyo problems caused by remarkable expansion of the Tokyo metropolitan area, although the major theme was the metropolitan area in general. Studies on the Osaka and Nagoya metro- 
politan areas were conducted independently or in comparison with the Tokyo metropolitan area. Takahashi and Taniuchi (1994) and Tomita (1995) studied Japan's three metropolitan areas, analyzing the transformation and future image of metropolitan areas. Yamamoto (1991) also edited a book about the Tokyo metropolitan area.

As already mentioned, urban studies in this period are characterized by those on urban systems. Since past studies on city regions or central places considered relations between central cities and subordinate cities, they can be classified as studies on urban systems. However, what specifically characterizes the recent study of urban systems is an approach aimed at clarifying interrelationships among major cities in terms of urban functions (Takahashi, N. 1978; Abe 1981; Morikawa 1994). While many past studies on city regions or central places focused on one region or city, there was an increase in studies that considered interrelationships at the national level, because rapid economic growth resulted in mass popular movement at the national level. Also, improved means of communication and transportation together with urban functions strengthened national networking and allowed researchers to study Japan as a whole from a national viewpoint.

Such a standpoint has been taken since the mid-1970s, as indicated by the establishment of the Urban System Working Group within the Association of Japanese Geographers in 1977. The 1980 IGC meeting held in Japan served to enhance this tendency, because many members of the above working group took part in its session of the Commission on National Settlement System, and had a chance to learn from researchers from all over the world. After that, research done mainly by the Japanese participants in this session was published in Tanabe (1982) and Yamaguchi (1985). Although the articles included in these two books were not necessarily based on the unified concept or analytical viewpoint of urban systems, the publication of these two books has in fact contributed a great deal to the progress of urban system study in Japan. It must be pointed out that urban system study then started to be con- ducted also from the viewpoint of quantitative geography (Murayama 1982; Sugiura 1987).

Analysis by high-level functions of cities became very effective in national-level analysis of urban systems. The central management function came to form the core analytical viewpoint in urban system study. Abe $(1984,1991)$ analyzed the rise and fall of the major Japanese cities and the changes in the Japanese urban system from the viewpoint of economic central management functions (head and branch offices of big private enterprises) from the early 20th century up to the present day. Hino (1984, 1991) and Teraya (1994) also analyzed urban systems from the same viewpoint, and Suda (1994) attempted to make a model of the urban cluster system focusing on this function.

Because of its concentration in the urban core, the central management function was also taken up in studies on the city's internal structure (Fujioka, H. 1981; Yamasaki 1989; Koga 1992). This function has become an important element in the study of the urban core as is true of retail and service functions. Matsubara $(1982,1985)$ considered, from a slightly different standpoint, the relations between city development and real estate businesses as providers of the office buildings which accommodate this function in the urban core.

The concentration of high-level urban functions in urban cores promotes vertical growth there. Todokoro (1986) did research on Nagoya which focused on this theme. While the United States offers some studies on skyscrapers in the metropolis, Japan has very few studies from this viewpoint, due to the basically low-level structure of Japanese cities.

Studies on non-metropolitan cities are largely divided into those on the impact of urbanization, on commercial functions, and on central places. In regard to the impact of urbanization, Aoki $(1980,1985)$ followed the traditional French concept of geography. T. Kagawa $(1984,1988)$ and Yui (1984) can be cited regarding the development of housing resulting from urbanization.

Many studies on commercial functions have considered the impact of large-scale retail facilities, because the location of large-scale retail facilities not only changes the regional struc- 
ture of commerce, but also affects the central place system. These were unlike past analysis of commercial functions which focused on urban functions. Accordingly, new and detailed studies based on the quantitative processing of consumer behavior appeared (Arai 1981; Fujii 1983; Matsuda 1984, 1991; Kawaguchi 1985; Itoh, O. 1986; Ishizawa 1987; Kagawa, K. 1987; Tomita 1987; Ikuta 1991). The increase in the number of urban studies from the viewpoint of wholesale functions is also remarkable in this period. The wholesale function is very useful when analyzing the extensive linkages among cities, urban systems and regional central cities, which are growing remarkably. Hasegawa (1984) and Nishihara (1994) represent those studies dealing with the wholesale function.

Central place study researchers have also produced many results in this period (Hayashi 1986; Morikawa 1987). A symposium on central place study was held in 1985 , and proceedings were published in Nishimura and Morikawa (1986), which showed how numerous central place researchers are in Japan. However, a question was raised regarding the validity of research which suggests that the existing hierarchy of central places in Japan is in accordance with Christaller's central place theory (Abe 1993).

A new trend was that studies emphasizing human perceptions and behavioral patterns emerged. Although this trend started in the 1970s (Nakamura 1978), such studies were few in number at that time. They dealt with such themes as consumer behavior and spatial perceptions, which certainly now form part of urban geography, while some people regard these themes as belonging to other fields in view of the research involved in them centering around the urban population. Several reports on the analysis of individuals' daily activities can be cited as research in fields such as behavioral or time geography (Okamoto 1983, 1995; Kamiya 1987; Takahashi, N. 1990; Kawaguchi and Kamiya 1991; Kamiya and Ikeya 1994).

There has been an increase in research on the inner city, especially on declining areas and gentrification; all of these have formed parts of urban geography. Such studies provide new insight into the internal structure of a city, contributing greatly to city planning, including the revitalization of cities. (Yamaguchi 1981; Mizuuchi 1982, 1984; Narita 1987; Fujitsuka 1992).

Another characteristic of this period is an increase in the number of studies emphasizing the information society. The city has long been pointed to as both the origin and destination of information, and relevant studies have been reported since the mid-1970s (Abe 1977; Kitamura and Terasaka 1979; Kitamura et al. 1989). The propagation of the GIS system in the 1990s, for example, will lead to further progress of studies in the geography of information.

Characteristics of this period include an increase in the number of studies on foreign cities and contributions to overseas journals by Japanese scholars (Kohsaka 1986, 1989; Sugiura $1986,1991,1993)$, and there has also been an increase in studies on Japanese cities by foreigners, which is attributed to the increased number of foreign students in Japan. It is a welcome situation that Japanese society as a whole has developed sufficiently to accept many foreign students, and that foreign scholars who know both their own country and Japan contribute to the promotion of comparative studies.

It is also significant that more precise quantitative approaches have been introduced. Quantitative analysis of a city dating back to the latter half of the 1960s has been well established as a field. Regular publication of works using quantitative analysis by younger geographers reflect the situation very well (Sugiura 1980; Ogata 1985; Itoh, S. 1986; Wakabayashi 1987; Murayama 1990, 1991; Ishikawa 1994).

In spite of a positive evaluation of the validity of quantitative approaches, they should not be approved unconditionally, because many of the analytical results obtained through quantitative approaches differ little from those obtained through nonquantitative approaches. A stance aiming at theoretical structuring of geography is not necessarily realized by quantitative approaches alone. The validity and limitation of quantitative approaches need further discussion. 


\section{Conclusions}

There are two aspects of urban geographical approaches, that is, to regard a city as a specific point or as an area. The former is represented by study of central places and of urban systems, while the latter is represented by study of the internal structure of the city. Researchers in Japanese urban geography can be evaluated as having dealt with these two aspects almost equally.

However, in either case, Japanese urban geography developed largely by applying imported foreign research results to Japanese cases for analysis. Although recently some younger researchers have been contributing to overseas journals, and an English-language journal Geographical Review of Japan, Series $B$ is now published in Japan, undeniably a trend of more inflow than outflow persists.

Urban geography in Japan will continue to develop, because urbanization, although slowing, is still progressing in Japan. Even if the urbanization stops, problems such as those inherent to the mature city will always exsist, as suggested by studies on inner city problems and gentrification. Moreover, internationalization will certainly make further progress as studies by Japanese on foreign cities will increase along with studies on Japanese cities done by foreign scholars. More opportunities for joint research and international conventions will ensure fruitful research results.

Controversy and theorization are indispensable for the further development of Japanese urban geography. The implications of the former are evident, judging from the role discussions played in the initial debate on urbanization. There can be no progress without controversy. Theorization is equally important. Although quantitative geography was originally strongly oriented toward theory, theorization can be accomplished without a quantitative approach. Whether quantitative or nonquantitative approaches are used is a question of attitude on the part of researchers.

(Received Dec. 1, 1995)

(Accepted May 25, 1996)

\section{References}

Abe, K. 1977. Note sur le flux inter-régional d'informations: A l'aide de données de telex. Annals of the Japan Association of Economic Geographers 23: 67-82. (JF)

Abe, K. 1981. Le développement de réseaux de filiales bancaires dans le Japon moderne. Annals of the Japan Association of Economic Geographers 27: 97-115. (JF)

Abe, K. 1984. Head and branch offices of big private enterprises in major cities of Japan. Geographical Review of Japan 57B: 43-67.

Abe, K. 1991. Nihon no toshi taikei kenkyu ( $A$ study on the urban systems in Japan). Kyoto: Chijin Shobo. (J)

Abe, K. 1993. On the hierarchy of cities in Japan. Human Geography 45: 94-105. (J)

AJG (The Association of Japanese Geographers) 1970. Japanese cities: A geographical approach. Special Publication 2. Tokyo: The Association of Japanese Geographers.

Aoki, E., Shirasaka, S., Nagano, M., and Fukuhara, M. eds. 1979. Gendai Nihon no toshika (Urbanization in modern Japan). Tokyo: Kokon Shoin. (J)

Aoki, N. 1980. On the discontinuous urbanization of Osaka in the period of Japan's industrial revolution. Human Geography 32: 1-22. (JE)

Aoki, N. 1985. Chiiki no gainen (Concepts of regions). Tokyo: Taimeido. (J)

Arai, Y. 1981. The role of the multi-good merchandising stores in the suburbanization of retail activity in a metropolitan region. Proceedings of the Department of Humanities, College of General Education, University of Tokyo, Series of Human Geography 7: 15-40. (JE)

Fujii, T. 1983. The locational change of retail functions in the Keihanshin metropolitan area: A phase in the development process of the metropolitan area. Human Geography 35: 210-232. (JE)

Fujii, T. 1990. Review of recent studies in the structure of the metropolitan area. Human Geography 42: 522-544. (JE)

Fujioka, H. 1981. Changes in locations of importexport firms and their relevance to the development of the core area of Kobe city. Geographical Review of Japan 54: 34-45. (JE)

Fujioka, K. 1955. Senshi chiiki oyobi toshiiki no kenkyu (A study on the prehistorical areas and the urbanized areas). Kyoto: Yanagihara Shoten. (J)

Fujioka, K. 1968. Nippon no toshi (Japanese cities). Tokyo: Taimeido. (J)

Fujitsuka, Y. 1992. Burgeon of gentrification in Nishijin, Kyoto. Human Geography 44: 495-506. (JE)

Geographical Review of Japan 1990. Special issue: Tokyo. 63B (1).

Hasegawa, N. 1974a. Trading areas of wholesaling of cities in Miyagi Prefecture: Spatial organization 
of marketing in the Tohoku cities (1). Annals of the Tohoku Geographical Association 26: 75-85. (JE)

Hasegawa, N. 1974b. Functional order and spatial system of cities as connecting-links in wholesaling activities: Spatial organization of marketing in the Tohoku cities (2). Annals of the Tohoku Geographical Association 26: 157-171. (JE)

Hasegawa, N. 1984. Ryutsu chiikiron (A geographical study of commodity distribution). Tokyo: Taimeido. $(\mathrm{J})$

Hattori, K. 1969. Daitoshi chiikiron (The metropolitan region). Tokyo: Kokon Shoin. (J)

Hattori, K., and Sugimura, N. 1974. Shotengai to shogyo chiiki (Shopping centers and commercial areas). Tokyo: Kokon Shoin. (J)

Hattori, K., Sugimura, N., and Higuchi, S. 1980. Urbanization and commercial zones. In Geography of Japan, ed. The Association of Japanese Geographers, 320-346. Tokyo: Teikoku Shoin.

Hayashi, N. 1973. On the spatial features of the central functions in Tokai area. Human Geography 25: 26-52. (JE)

Hayashi, N. 1986. Chushinchi riron kenkyu (Studies on the central place theory). Tokyo: Taimeido. (J)

Hayashi, N., and Ito, Y. 1976. The central place system in Ichinomiya urban area in Aichi Prefecture. Human Geography 28: 589-620. (JE)

Higuchi, S. 1956. The comparative geography of "C.B.D." Ritsumeikan Literature Review 137: 740752. (J)

Higuchi, S. 1963. Shogyo chiikiron (Commercial geography). Kyoto: Chijin Shobo. (J)

Higuchi, S. 1979. Toshi no naibu kozo (Internal structure of cities). Tokyo: Kokon Shoin. (J)

Hino, M. 1984. The location of head and branch offices of large enterprises in Japan. Science Reports of the Tohoku University, 7th Series (Geography) 34 (2): 41-60.

Hino, M. 1991. The locational patterns of branch offices of multi-locational enterprise in the San-in region, western Japan. Annals of the Tohoku Geographical Association 43: 245-263. (JE)

Ikuta, M. 1991. Daitoshi shohisha kodo ron ( $A$ theory on metropolitan consumer behavior). Tokyo: Kokon Shoin. (J)

Ishikawa, Y. 1994. Jinko ido no keiryo chirigaku (Quantitative geography of migration). Tokyo: Kokon Shoin. (J)

Ishimizu, T. 1962. The present status of urbanization studies in Japanese academic circles of geographers. Geographical Review of Japan 35: 362-373. $(\mathrm{JE})$

Ishimizu, T. 1976. Keiryo chirigaku gaisetsu (An outline of quantitative geography). Tokyo: Kokon Shoin. (J)

Ishimizu, T., and Ishihara, H. 1980. The distribution and movement of the population in Japan's three major metropolitan areas. In Geography of Japan, ed. The Association of Japanese Geographers, 347-378. Tokyo: Teikoku Shoin.

Ishimizu, T., and Okuno, T. eds. 1973. Keiryo chirigaku (Quantitative geography). Tokyo: Kyoritsu Shuppan. $(\mathrm{J})$

Ishizawa, T. 1987. Changes of retail central place system in Miyagi Prefecture. Geographical Review of Japan 60A: 455-465. (JE)

Ito, G. ed. 1972. Chukyo ken (Nagoya metropolitan area). Tokyo: Taimeido. (J)

Itoh, O. 1986. Urban retail structure and consumer behavior in Tottori. Journal of the Faculty of General Education, Tottori University 20: 29-62. (J)

Itoh, S. 1986. An analysis of the distance parameter of spatial interaction model: A case of the greater Tokyo metropolitan area. Geographical Review of Japan 59B: 103-118.

Kagawa, K. 1987. The influence of big stores expansion into small cities on retail trade: Focusing on influences on the retailing function and central shopping district. Human Geography 39: 216-233. (JE)

Kagawa, T. 1984. Location of multi-storied residential buildings in the urban central area: A case study in Nagoya City. Human Geography 36: 362-375. (J)

Kagawa, T. 1988. Changes within the surrounding area of $\mathrm{CBD}$ as affected by the construction of condominiums: a case study of Osaka City. Geographical Review of Japan 61A: 350-368. (JE)

Kamiya, H. 1987. Daily activities of housewives in Nagoya City. Human Geography 39: 19-35. (JE)

Kamiya, H., and Ikeya, E. 1994. Women's participation in the labour force in Japan: Trends and regional patterns. Geographical Review of Japan 67B: 1535.

Kawaguchi, T. 1985. Spatial structure of retail activities in the Tokyo commuting area. Geographical Review of Japan 58A: 744-753. (JE)

Kawaguchi, T., and Kamiya, H. 1991. Human activity studies in an urban environment: A review. Human Geography 43: 44-63. (JE)

Kitagawa, K. 1962. Development of the city as the center of the large region in Japan. Human Geography 14: 242-262. (JE)

Kitagawa, K. 1976. Koiki chushinchi no kenkyu (A study of regional capital city). Tokyo: Taimeido. (J)

Kitamura, Y., and Terasaka, A. eds. 1979. Ryutsu jyoho no chiiki kozo (Regional structure of circulation and information). Tokyo: Taimeido. (J)

Kitamura, Y., Terasaka, A., and Tomita, K. eds. 1989. Johoka shakai no chiiki kozo (The regional structure of an information-oriented society). Tokyo: Taimeido. (J)

Kiuchi, S. 1951. Toshi chirigaku kenkyu (Urban geography). Tokyo: Kokon Shoin. (J)

Kiuchi, S. ed. 1955. Jinko shuraku chiri (Population) settlement geography). Shin chirigaku koza (New geography course) 5. Tokyo: Asakura Shoten. (J) 
Kiuchi, S. ed. 1967. Toshi sonraku chirigaku (Urban) rural geography). Asakura chirigaku koza (Asakura geography course) 9. Tokyo: Asakura Shoten. (J)

Kiuchi, S. 1979. Toshi chirigaku genri (Principles of urban geography). Tokyo: Kokon Shoin. (J)

Kiuchi, S., and Tanabe, K. eds. 1971. Koiki chushin toshi (Reginal central cities). Tokyo: Kokon Shoin. (J)

Kiuchi, S., Yamaga, S., Shimizu, K., and Inanaga, S. eds. 1964. Nihon no toshika (Urbanization in Japan). Tokyo: Kokon Shoin. (J)

Kobayashi, H. 1950. Group cities in the United States. Human Geography 2: 47-59. (JE)

Koga, S. 1992. Office location in the central area of Takamatsu. Human Geography 44: 21-46. (JE)

Kohsaka, H. 1972. The internal structure of city level trade area: An analysis of consumer shopping behavior. Geographical Review of Japan 45: 756773. (JE)

Kohsaka, H. 1976. The internal structure of city level trade area: An analysis of shopping behavior for daily shopping goods in Shimizu City. Geographical Review of Japan 49: 595-615. (JE)

Kohsaka, H. 1986. The location process of central place system within a circular city. Economic Geography 62: 254-288.

Kohsaka, H. 1989. A spatial search-location model of retail centers. Geographical Analysis 21: 338-349.

Kunimatsu, H. 1934. Toshi chiri josetsu (An introduction to urban geography). Tokyo: Kokon Shoin. (J)

Kuwajima, K. 1964. Development of central shopping street. Geographical Review of Japan 37: 649-660. (JE)

Kuwajima, K. 1971. Toshi no kino chiiki (Functional areas within the city) Tokyo: Taimeido. $(\mathrm{J})$

Matsubara, H. 1982. The development of large-scale residential estates by private developers in Japan. Annals of the Japan Association of Economic Geographers 28: 279-295. (JE)

Matsubara, H. 1985. Locational characteristics of multistory apartment house by private developers in Japan. Annals of the Japan Association of Economic Geographers 31: 81-97. (JE)

Matsuda, T. 1984. The central place system in view of location theory: A case study of the fringe of a metropolitan area. Human Geography 36: 63-75. (J)

Matsuda, T. 1991. Small-scale retail stores in central Kyoto under the Large-Scale Retail Store Act: A case of perishable foods. Annals of the Japan Association of Economic Geographers 37: 334-353. (JE)

Mizuuchi, T. 1982. Formation and development of the inner city in Osaka during the Japanese industrialization. Human Geography 34: 1-25. (JE)

Mizuuchi, T. 1984. Densely inhabited districts of poorer people and renewal projects in 6 big cities in pre-war Japan: Through an analysis of the
"Renewal of Poor Housing Districts Act" of 1927. Human Geography 36: 1-23. (JE)

Morikawa, H. 1959. Verteiling der zentralen Siedlungen und ihre Entwicklung im Regierungsbezirke Hiroshima. Geographical Review of Japan 32: 595-613. (JG)

Morikawa, H. 1961. Wandelungen des Systems der zentralen Orte in Kumamoto Provinz. Geographical Review of Japan 34: 471-486. (JG)

Morikawa, H. 1968. Central-place hierarchy and city size distribution. Human Geography 20: 66-87. (J)

Morikawa, H. 1969. Zwei Wandlungstypen der zentralörtlichen Hierarchie in Japan. Geographical Sciences 12: 36-47. (G)

Morikawa, H. 1974. Chushinchi kenkyu (Central places). Tokyo: Taimeido. (J)

Morikawa, H. 1976. A classification of municipalities in Hiroshima Prefecture with using multivariate analysis. Geographical Review of Japan 49: 736754. (JE)

Morikawa, H. 1987. Central place system in the Chugoku District, southwestern Japan: As a base of regional planning. Geographical Reports of Tokyo Metropolitan University 22: 189-209.

Morikawa, H. 1994. Regional structures of economic linkages between Japanese cities based on the analysis of bank branch networks. Human Geography 46: 46-66. (JE)

Murayama, Y. 1982. Diffusion channels of innovation in the urban system: The case of Lions Clubs. Annals of the Tohoku Geographical Association 34: 224-236. (JE)

Murayama, Y. 1990. Chiiki bunseki (Regional analysis). Tokyo: Kokon Shoin. (J)

Murayama, Y. 1991. Kotsu ryudo no kukan kozo (Spatial structure of traffic flows). Tokyo: Kokon Shoin. (J)

Nakamura, Y. 1978. Mental maps and geographic space in Nagoya. Geographical Review of Japan 51: 1-21. (JE)

Narita, K. 1967. Urban population changes and the economic base theory. Shirin 50(3): 110-137. (J)

Narita, K. 1987. Daitoshi suitai chiku no saisei (The revitalization of declining areas in great cities). Tokyo: Taimeido. (J)

Nishihara, J. 1975. The distribution of population density and dwelling area per person: A case study of Sendai City. Annals of the Tohoku Geographical Association 27: 169-175. (JE)

Nishihara, J. 1994. Inter-urban linkages and systems of cities; The case of wholesaling activity in Kyushu Province, Japan. Geographical Review of Japan 67 A: 357-382. (JE)

Nishimura, M. 1965. Relationship between centralityindex and distance and the construction of equilibrium circle. Human Geography 17: 565-587. (JE)

Nishimura, M. 1977. Chushinchi to seiryokuken (Central places and spheres of influence). Tokyo: Tai- 
meido. (J)

Nishimura, M., and Morikawa, H. eds. 1986. Chushinchi kenkyu no tenkai (Evolution of central place studies). Tokyo: Taimeido. (J)

Odauchi, T. 1918. Teito to kinko (Imperial capital and its suburbs). Tokyo: Okura Kenkyusho. (J)

Ogasawara, S. 1967. Population movement in Sapporo metropolitan area. Science Reports of the Tohoku University, 7th Series (Geography) 16: 8593.

Ogata, N. 1985. Factorial ecology in space and time of a city: The daily rhythm of population of Himeji City. Human Geography 37: 1-19. (JE)

Okamoto, K. 1983. Cognitive distance in Nagoya City. Geographical Review of Japan 56: 695-713. (JE)

Okamoto, K. 1995. The daily activities of metropolitan suburbanites and the urban daily rhythm: the case of Kawagoe, a suburb of Tokyo, and Nisshin, a suburb of Nagoya. Geographical Review of Japan 68A: 1-26. (JE)

Okuno, T. 1977. Keiryo chirigaku no kiso (The fundamentals of quantitative geography). Tokyo: Taimeido. $(\mathrm{J})$

Okuno, T., and Nishioka, H. 1976. Quantitative geography in Japan: Introduction to the special issue. Geographical Review of Japan 49: 421-426. (J)

Osaka City Office 1970. Chusu kanri kino chosa hokokusho (Report on the central management functions) 3. Osaka: Osaka City Office. (J)

Otomo, A. 1979. Nihon toshi jinko bumpuron (Geographical distribution of urban population in Japan). Tokyo: Taimeido. (JE)

Sawada, K. 1978. Nihon no toshiken (Urban regions in Japan). Tokyo: Kokon Shoin. (J)

Suda, M. 1994. A model of optimal spatial allocation of branch offices from the viewpoint of communication cost: In the case of a given urban system. Human Geography 46: 515-527. (JE)

Sugimura, N. 1967. Urban structure of Sendai seen from the distribution of shoppers at central shopping street. Annals of the Tohoku Geographical Association 19: 200-207. (JE)

Sugimura, N. 1975. Chushin shotengai (Central shopping streets). Tokyo: Kokon Shoin. (J)

Sugiura, Y. 1980. An INDSCAL approach to spatial analysis of innovation diffusion: The case of radio subscription in the Tokai district. Human Geography 33: 1-22. (JE)

Sugiura, Y. 1986. Diffusion of Rotary Clubs in Japan, 1920-1940: A case of non-profit-motivated innovation diffusion under a decentralized decision making structure. Economic Geography 62: 125143.

Sugiura, Y. 1987. Spatial diffusion of electricity supply companies through a system of cities in Japan, 1887-1898. Geographical Reports of Tokyo Metropolitan University 22: 67-84.

Sugiura, Y. 1991. A map-transformation approach to the location of central places: the case of the central Kanto region in preindustrial Japan. Environment and Planning $A$ 23: 969-985.

Sugiura, Y. 1993. Spatial diffusion of Japanese electric power companies, 1887-1906: A discrete choise modeling. Annals of the Association of American Geographers 83: 641-655.

Suzuki, F. 1975. Keiryo chirigaku joron (Introduction to quantitative geography). Kyoto: Chijin Shobo. (J)

Takahashi, J. 1975. Quantitative geography: present and future. Chiri 20(1): 33-43. (J)

Takahashi, J., Saino, T., Ishikawa, J., Ishizuka, K., and Sugiura, N. 1976. Implications of quantitative revolution in geography. Geographical Review of Japan 49: 427-439 (JE).

Takahashi, N. 1968. The progress of urbanization with industrialization of the Numazu-Mishima area. Geographical Review of Japan 41: 1-18. (JE)

Takahashi, N. 1978. Territorial structure of small and medium financial institutions in Japan. Geographical Review of Japan 51: 22-37. (JE)

Takahashi, N. 1979. Quelques aspects de l'urbanisation au Japon. Tsukuba Studies in Human Geography 3: 85-93. (F)

Takahashi, N. 1980a. Thémes et perspectives de la recherche en géographie urbaine au Japon. Annual Report of the Institute of Geosciences, the University of Tsukuba 6: 22-28. (F)

Takahashi, N. 1980b. Le développement de l'urbanisation au Japon. Espace Géographique 2: 105-119. (F)

Takahashi, N. ed. 1990. Nihon no seikatsu kukan (Life space in Japan). Tokyo: Kokon Shoin. (J)

Takahashi, N. and Kanno, M. 1988. A review of studies on metropolitan areas in Japan. Geographical Review of Japan 61B: 111-119.

Takahashi, N., and Taniuchi, T. eds. 1994. Nihon no sandai toshiken: Sono henyo to shoraizo (The three metropolitan areas in Japan: Changing spatial structure and future perspectives). Tokyo: Kokon Shoin. (J)

Takano, F. 1959. The types and definition of "urbanization." Geographical Review of Japan 32: 629642. (JE)

Takano, F. 1962. A study of the regional structure of city-region pattern: An example of Tokai district, central Japan. Geographical Reports (Aichi University of Education) 19: 1-46. (JE)

Tanabe, K. 1949. A geographical study on the reestablishment of the destroyed city Sendai. Geographical Review of Japan 22: 264-273. (J)

Tanabe, K. 1971. Toshi no chiiki kozo (Areal structure of city). Tokyo: Taimeido. (J)

Tanabe, K. 1973. Recent changes in the central area of Japanese cities. Science Reports of the Tohoku University, 7th Series (Geography) 23: 187-201.

Tanabe, K. 1975. Development of urban geography in Japan from the viewpoint of the growth of urban geographers. Annals of the Tohoku Geographical Association 27: 189-196. (JE) 
Tanabe, K. ed. 1982. Nihon no toshi shisutemu (Urban system in Japan). Tokyo: Kokon Shoin. (J)

Tanabe, K. 1985. Development stages and contemporary problems of urban geography. Toshi Mondai (Municipal Problems) 76(1): 60-66. (J)

Tanabe, K., Takano, F., and Futagami, H. eds. 1977. Toshin saikaihatsu (Renewal of civic centers). Tokyo: Kokon Shoin. (J)

Tanabe, K., and Watanabe, Y. eds. 1985. Toshi chirigaku (Urban geography). Sokan chirigaku koza (General treatise of geography) 16. Tokyo: Asakura Shoten. $(\mathrm{J})$

Teraya, R. 1994. Characteristics of branch offices and the hierarchy of cities in Hokkaido Prefecture. Memoirs of the Faculty of General Education, Ehime University 27: 1-30 (JE).

Todokoro, T. 1973. The location of multi-storied buildings in Takasaki. Human Geography 25: 4967. (J)

Todokoro, T. 1975. Vertical growth of C.B.D. in the City of Nagoya. Geographical Review of Japan 48: 831-846. (JE)

Todokoro, T. 1986. Toshi kukan no rittaika (Vertical growth of urban space). Tokyo: Kokon Shoin. (J)

Tomita, K. 1975. Changing patterns of population and industries in the metropolitan areas of Japan. Geographical Review of Japan 48: 331-350. (JE)

Tomita, K. 1977. Recent locational trends of retail and service activities in the Nagoya metropolitan area. Geographical Review of Japan 52: 559-577. (JE)

Tomita, K. 1987. Changes in structures of retail trade area in Chiba Prefecture, 1969-1983. Geographical Reports of Tokyo Metropolitan University 22: 99-109.

Tomita, K. 1995. Daitoshiken no kozoteki henyo (Structural changes in the metropolitan areas in Japan). Tokyo: Kokon Shoin. (J)

Tsutsumi, M. 1975. A study of the hierarchical systems of central place in Fukushima Prefecture. Human Geography 27: 227-251. (JE)

Wakabayashi, Y. 1987. Urban factorial ecology in space and time within the city region of Hiroshima. Geographical Review of Japan 60A: 431454. (JE)

Watanabe, Y. 1954. The service pattern in the Shinjo Basin, Yamagata Prefecture: A research in a less populated basin in Japan. Science Reports of the Tohoku University, 7th Series (Geography) 3: 77-90.

Watanabe, Y. 1955. The central hierarchy in Fukushima Prefecture: A study of types of rural service structure. Science Reports of the Tohoku
University, 7th Series (Geography) 4: 25-46.

Yamada, M. 1988. Recent trends in urban geography. Toshi Mondai Kenkyu (Journal of Municipal Problems) 40: 96-111. (J)

Yamaga, S. 1950. Urawa, the satellite city of Tokyo. Geographical Review of Japan 24: 53-59. (JE)

Yamaga, S. 1967. Tokyo daitoshiken no kenkyu ( $A$ study on the Tokyo metropolitan area). Tokyo: Taimeido. (J)

Yamaga, S. 1968. Some development trends for the surrounding areas of Tokyo. Bulletin of Tokyo Gakugei University 20: 108-116.

Yamaga, S. 1973. Process of urban geographical studies in Japan. Geographical Review of Japan 46: 488-491. (J)

Yamaguchi, T. 1972. Parallel structure of urban functions in Japan. Geographical Review of Japan 45: 411-429. (JE)

Yamaguchi, T. 1973. Some procedures for classifying Japanese cities. Proceedings of the Department of Humanities, College of General Education, University of Tokyo, Series of Human Geography 4: 73-96. (JE)

Yamaguchi, T. 1981. Gentrification: A review of evidence in American Cities. Proceedings of the Department of Humanities, College of General Education, University of Tokyo, Series of Human Geography $7:$ 41-52. (JE)

Yamaguchi, T. ed. 1985. Sekai no toshi shisutemu (Urban systems in the World). Tokyo: Kokon Shoin. (J)

Yamaguchi, T. 1988. Recent changes in Japan's urban system: A review. Proceedings of the Department of Humanities, College of Arts and Sciences, University of Tokyo, Series of Human Geography 10: 71-84.

Yamamoto, S. ed. 1991. Shutoken no kukan kozo (The spatial structures of Tokyo metropolitan area). Tokyo: Ninomiya Shoten. (J)

Yamasaki, T. 1989. Perspectives on the changes in urban structure in terms of office location. Geographical Sciences 44: 156-166. (J)

Yoshida, H. 1970. Agglomeration of the branch offices in the regional central cities. Geographical Review of Japan 43: 183-189. (JE)

Yoshida, H. 1972. Some notes on the city function of Sendai: An introductory study for the regional central cities. Journal of Geography (Chigaku Zasshi) 81: 25-43. (JE)

Yui, Y. 1984. The housing estates in Hiroshima City: Their developments and their residential structure. Human Geography 36: 152-170. (JE) 